\title{
Increasing Students' Reading Comprehension Skill by Using Written Text Book
}

\author{
Edwin Nuvianto Al Azis', Gita Yusanti² \\ IAIN Kediri \\ nuviantoe@gmail.com¹, gitayusanti@gmail.com²
}

\begin{abstract}
The purpose of this article is deeply to review some issues about increasing students' reading comprehension skill by using written text. One of the important point in increasing students' reading comprehension skill is by giving them written text which can attract their interest, such as: comic, novel, short story, storytelling, etc. Some other issues about students' reading skill are also interesting to be discussed, for example teaching reading methods, the benefits and the problems in teaching reading skill by using written text. The high percentage of success in increasing students' reading skill is really important to make sure that they have input in mastering or improving their English. However, increasing students reading comprehension skill is not easy and it needs to be discussed to figure the best way out.
\end{abstract}

Keywords: reading comprehension, written text, methods

\section{INTRODUCTION}

In English there are four skills, such as: reading, speaking, listening and writing. However, this paper focuses on reading skill. Moreover, we can also apply teaching reading via many methods or teaching ways, state theories of reading comprehension, review the effective strategies for reading comprehension, and one of good methodsin reading comprehension. The right strategy can improve reading comprehension (Syafi'I, 2015; Rohman, 2017). Syafi'I (2015) suggests that SMART strategy to reading comprehension. However, Rohman (2017) text structure tasks become a strategy to reading comprehension.According to Topuzkanamis (2019), the number of texts to read has been constantly increasing in recent years. In addition, opportunities to produce written texts have been thriving in humankind's favor. Actually, written text is too general to be learnt by some people. Written text here means some passages which will be able to attract the students' curiosity, such as: comic, novel, short story etc.

According to previous study conducted by Rohman (2017),Text Structure Tasks which are prepared can improve the English students' reading comprehension skill. It is shown by the increasing students' mean score 67.65 in pre-test to75.88 in posttest. From four acts in the cycle, it can be concluded that there are six steps done to improve the students' reading comprehension through text structure tasks. They are: 1). asking the students the type of writing the writer uses; 2). asking the students to find the way the writer organizes the text; 3 ). asking the students to find how the text is developed; 4). asking the students to work in pair and find how the idea is classified into groups; 5). asking the students 
to find what the main idea of paragraphs is; and 6). asking the students to find how each paragraph is related to each other. From the idea above, it can be clarified that to help the students construct meaning and integrating information from the text.

Using those kinds of interesting written text books are intended to increase students' reading comprehension skill (Ghali, 2019). That way can be applied in teaching English particularly on teaching reading in order to omit students' bad perception or impression about reading. Apparently, reading is really important skill to improve students' English mastery. So, using text book will help more in teaching reading (Muzammil, 2017). It is also like good innovation in teaching reading world by using their interest in some written text. Therefore, it is really important to investigate or to comprehend more deeply about increasing students' reading comprehension skill by using written text, how to teach reading through written text, the benefits and problems that arise in teaching reading by using written text book as well.

According to Steve (2009), comprehension is the only one reason or condition in reading. Without comprehension, reading is a frustrating, useless exercise in word calling. Several years ago, teaching reading comprehension was based on the concept of reading as set of application skills, such as: identifying words, finding main ideas, identifying cause and effect relationship, comparing and contrasting, and sequencing (Steve, 2009). Those are as mastery skills in reading. When we figure out in teaching reading or reading learning process, we will be able to find out those common things or questions which are questioned in reading or written text. Some passages actually do not only contain those skills but also another skill such as: pronunciation in reading it aloud, the sentence structure or grammatical structure as well (Nunan, 2003).

According to Gilakjani and Sabouri (2016), reading as the process of making meaning from written texts. It needs the harmony of a lot of related sources of information. It is the process of creating meaning that involves: (a) the reader's existing knowledge; (b) the text information; and (c) the reading context. Reading activity is not only a source of information and a pleasurable activity but also as a means of consolidating and extending one's knowledge of the language. Reading activity is needed to widen the mind and to gain the understanding of the foreign culture (Putranti \& Supriyanti, 2015).So, the main goal of reading is to gain the correct message from a text that the writer intended for the reader to receive.

Apparently, reading is also about expanding our vocabulary. It means that by reading we will be able to reach some benefits or goals in one step. We can not deny that reading is one of important skills. The skills which are in teaching reading for getting students' comprehension should not only focus on old or classical skills like the common question, but also expand it by making or driving the students on understanding or comprehending the meaning structure. It means not only it focuses on finding the answer of classical theory such as main idea, but also it can be in retelling the passages by short way or summarizing by using their own words.

Gilakjani and Sabouri (2016) defined reading comprehension as the process of creating meaning from text. The purpose is to get an understanding of the text rather than to acquire meaning from individual words or sentences. The outcome of reading comprehension is the mental representation of a text meaning that is combined with the readers' previous knowledge. Therefore, these sources are

\section{ENGLISH EDUCATION}

Journal of English Teaching and Research 
different based on the skill levels and age of readers. Learning to read refers to reading for meaning or comprehension. Reading for meaning is essentially an attempt to comprehend texts. It involves all the activities of reading for meaning (Hamra, 2010). This definition implies that readers bring their background, experiences, and emotion into play. Consequently, upset students will bring their feelings into the act of reading, and this kind of situation will affect the reading process. Students who have more knowledge of the reading matter will get more from the material than the students who are less knowledgeable. A student who is good at critical thinking will get more than someone who is not.

The most important thing in teaching comprehension skill is stimulant or how to stimulate all skills which are in the students' selves (Gilakjani \& Sabouri, 2016). It is intended to succeed the pure meaning of teaching in general context. It is not kind of teaching by teacher center but it is like facilitation from the teacher in learning process particularly in reading learning. Comprehension is not also only about the general meaning itself, but also about everything which are related with skills in reading context. It means that reading comprehension skills by using written text is not about the surface or general meaning itself, but we can surf in depth of that meaning. Therefore, it is to help students to develop the knowledge, skills, and experiences they must have if they are to become competent and enthusiastic readers.

\section{TEACHING READING BY USING WRITTEN TEXT}

Apparently, the most important thing in teaching reading is the way how to make our students or learners becoming individual or autonomous readers (Buehl, 2001). It means that we teach them by giving or even changing their mindset or perception in reading activity. We have to attract their curiosity by giving them written text which will give them spirit to read (see appendix 1). The genuine meaning of teaching is how to teach and make the students to understand more about the material. It is not about from teachers' viewpoint when we teach them just delivering the material and we are sure that they will understand. However, it is also about making or driving them to have continuous effect like becoming autonomous readers.

According to Rohman (2017), other way to increase the students' comprehension is by doing the text structure tasks. What the students do is doing the text structure tasks orally. It can be clarified that to help the students construct meaning, integrating information from the text, the teacher can use text structure tasks because by doing the tasks for example by asking the students some questions related to text structure the students will get easily to understand the comprehension questions. However, the problem of teaching text understanding to a classroom full of students who come from diverse cultural and language backgrounds, the researcher has to take responsibility and take my individual initiative for improving the classroom in which the researcher work.

Elucidating deeply the real meaning of reading means that the readers should understand well about what they need to get from that reading activity, such as: the accuracy of the passage, the comprehension, and the follow up. It is meant to make the readers get more knowledge (Ness, 2009). So, teaching reading by using written text here means teaching the students with giving them the written text which is considered appropriate to their level of comprehension (Chastain, 1989).

As the example, one of teaching reading goals at the junior high school as stated in the standard of content (Depdiknas, 2006) is to enable the students to 
understand the formal or informal written text which are in the forms of recount, procedure, descriptive, report and in the context of daily life. As a teacher we must find some dares or obstacles in delivering our explanation. To make us easier in the teaching reading, we need to make the concept well, such as: making the preparation in the situations which will appear in the process and possibilities. It is perhaps on well-prepared lesson plan, power point, passage, and some icebreaking because the reading section mostly feels boring for the students. So, we need to anticipate it by making some appropriate learning strategy, such as interesting topic, picture and game. Another method in teaching reading is grading the ability and giving them the appropriate passages based on their level. On the other hand understanding their interest and need are also important to be considered. The data shows that some children in Indonesia have interest in reading book in Bahasa Indonesia and the others have interest in reading passage with English language. (See appendix 2 and 3).

According to Chong et all (2018), Extensive reading (ER) enables students to reap numerous linguistic benefits, including improved reading fluency. ER provides students with a lot of easily comprehensible English books of various genres, allowing them to enjoy the learning process while improving their reading proficiency at the same time. In 2002, Day and Bamford (pp. 137-141) developed 10 principles of ER which could be regarded as the key ingredients of a successful ER program and encouraged teachers to use them. The 10 principles were:

1. The reading material is easy

2. A variety of reading material on a wide range of topics is available.

3. Learners choose what they want to read.

4. Learners read as much as possible.

5. Reading is for pleasure, and to gain information and general understanding.

6. Reading is the reward itself.

7. Learners generally read quickly and not slowly.

8. Reading is silent and individual.

9. Teachers orientate and provide guidance to students.

10. The teacher models being a reader.

\section{THE BENEFITS OF READING THROUGH WRITTEN TEXT}

Benefit is one of important points that should be discussed in teaching reading. It is because by looking at the benefits we will be able to know how far success which will be gotten. By looking the benefits we will also be able to consider the risen problems. In other words the benefits of teaching reading through written text is everything that will be gotten by doing the reading activity through written text which will be possible for students to acquire the expansion of knowledge. Written text is kind of classical theory in teaching reading, but we will be able to perceive its flying number.

According to Ghali (2019), written text is the most effective way in implementing teaching reading to the students than the others way or method. However, we need to modify the written text which we will give or show to students. In other word, we need to consider their interest in certain passage or it can attract their curiosity in reading the passage and hopefully students will continue the reading activity or become autonomous readers. That data has been observed and implemented by some schools, and it can reveal the result in some Indonesian schools. (See appendix 4).

\section{ENGLISH EDUCATION}

Journal of English Teaching and Research 
Reading textbook has significant impacts to improve the writing skills of EFL students (Habibi, 2015). It was instead viewed as a process of pedagogy (prewriting, drafting and post writing) through which students learned to make a relationship between what they read and what they tend to write.To make sure in reaching the benefits, we have to make the plans or strategies well, such as: the time, the material etc. (see appendix 5). We also need to consider in which level they are and categorize their needs. If whole complements are ready, the flying number is real too. These are some benefits in list in teaching reading through written text:

1. It can attract students' curiosity;

2. It can make them continue the reading activity;

3. It can make them become autonomous readers;

4. It can change their bad impression or perception;

5. It will rehearse their brain;

6. It can improve their concentration;

7. It will be able to improve their vocabulary and language skills;

8. It can develop their imagination (Steve, 2009).

We can conclude that when we have made all of the plans well, we will be able to know the percentage of the success. We also need to look at their interest need, and the level ability. We need to give our extra time and effort if we want to implement this way or method. However, by looking at the benefits we will not be able to rewind.

In this section, we will begin by synthesizing the findings from two metaanalyses on Reading comprehension by Steve (2009) and Chong (2019), which encompass the effects of Extensive reading on reading rate, reading comprehension and vocabulary. In addition, these meta-analyses also investigated the impact of variables such as age, and length of instruction on the effects of extensive reading. After reviewing the findings of these two meta-analyses, I will categorize the remaining papers into two large categories: (a) the effects of ER on specific language skills and (b) students' attitudes and perceptions toward ER. Important research gaps will be highlighted for each category and recommendations for future research will be put forward after a review of all articles.

\section{THE PROBLEMS OF READING BY USING WRITTEN TEXT}

Problems are common thing in everything. It is like the obstacles which will be gotten by everyone in doing certain activities. However, we can still anticipate whole risen problems by figuring it out well or doing even reading some related articles. Risen problems of teaching reading by using written text here means all of the obstacles which will appear as long as the process in implementing that way. It can be from the students, facilities, activities, or even the teachers (Ghali, 2019).

Apparently, the problems are always the same from one student to another or one material, teacher, or activity to another. It is like common problems or general problems, such as: boredom, monotonous unenthusiasctics passages. By doing this method, the teachers need to make sure that they have more time or extra time in knowing each student's interest. It will take long time but we can not deny the good result. Beside that low comprehension or teachers' awareness in implementing this strategy is still less. It also needs the cooperation between all elements in order to come to the goals. However, it is not complicated problems if we figure it out together among whole elements. 
These are some risen problems in teaching reading by using written text:

1. Issues with decoding

It is also known as sounding out words, decoding is when children can put sounds to letters in order to sound out written language. It is common for beginner readers to struggle when they meet strange term. Reading a passage involves decoding, comprehension, and the interaction between the two processes. Until recently, however, reading assessment and research on reading disability has focused mainly on word decoding skills. This emphasis was likely because decoding is primary to comprehension, and because decoding failures are more easily defined than comprehension failures, thus rendering understanding decoding a more tractable problem than understanding comprehension (Keenan et all, 2008).

2. Poor comprehension

There are a lot of things in reading, from letter and word recognition to understand meaning at the phrase, sentence, and paragraph level. In other word when the beginner encounters new vocabulary they will just skip it. According to Keenan (2008) there are many test formats used in constructing reading comprehension tests. Among them are (a) whether reading is oral or silent, (b) the length of the passage, and (c) the particular type of comprehension assessment.Reading habit can be categorized into very low, rather low, medium, high, and very high. It is measured from several aspects such as the number of reading practices, vast amount of time provided for reading, good proficiency in English (Atayeva et all, 2019). So, poor comprehension is influenced by a person's reading habit.

3. Speed

The more students read, the more they encounter unfamiliar terms. They just guess by using their prior knowledge.Therefore, it needs cooperation from whole aspect, such as: students, teachers, and the government in order to succeed it. It can be fixed by preparing all possibilities and obstacles which will appear.Perwira et all (2019) states readability is one of the aspects needed to make the students are interested in reading textbook. He claimed that the textbook has several positive impacts on language learning. It also has the benefit of keeping the quality of the organization of the course and syllabus. A good textbook is made to be well structured to allow learners to follow and make sense of the content. It should also have graphics to help understanding by giving a pictorial representation of ideas, which facilitate the ease of remembering information. In the textbook, there should be references to other related sources. A good textbook also includes exercises, which learners can use to test their skills. So, textbooks should also trigger critical thinking for students and it affects the level of student reading speed.

\section{CONSCLUSION}

The term of teaching reading by using written text is not something new, it is just like classical theory which has been modified to adapt with recent condition. All aspects in bad or possibilities should be anticipated by preparing it well. We can also perceive the high number of success or benefits as long as we recognize it well. It is like making it as decoration if we just let the common problem come and go in other word without cooperation. Therefore, it is like the decision where it will be taken, and how we will solve the obstacles by searching the solution without rewinding.

\section{ENGLISH EDUCATION}

Journal of English Teaching and Research 


\section{REFERENCES}

Atayeva, M., Kassymova, G., Setyo, P.N.H.P., \& Kosbay, S. (2019). Impact of reading on students' writing ability. Materials of International Practical Internet Conference "Challenges of Science".2, 5-13. https://doi.org/10.31643/2019.001

Buehl, Doug. (2001). Classroom Strategies for Interactive Learning. Newark: International Reading Association.

Chastain, Kenneth. (1989). Developing Second Language Reading Skills: Theory and Practice. New York: Harcowth Brace Javanovich Publisher.

Chong, M.Y.C., Ng, Q.R., \& Renandya, W.A. (2019). Extensive Reading: Theory, Research and Implementation. TEFLIN Journal. 30(2), 171-186. DOI: http://dx.doi.org/10.15639/teflinjournal.v30i2/171-186

Depdiknas, (2006). Kurikulum Standar Kompetensi Mata Pelajaran bahasa Inggris Sekolah Lanjutan Pertama dan Madrasah Tsanawiyah. Jakarta: Departemen Pendidikan Nasional.

Gilakjani, A.P, \& Sabouri, N.B. (2016). How Can Students Improve Their Reading Comprehension Skill?Journal of Studies in Education. 6(2), 229-240. http://dx.doi.org/10.5296/jse.v6i2.9201

Habibi, H., Salleh, A.H., \& Singh, M.K.S.(2015). The Effect of Reading on Improving the Writing of EFL Students. Pertanika Journal Social Science. \& Humanities. 23(4). 115-1138

Hamra, Arifuddin., \& Syatriana, Eny. (2010). Developing A Model Of Teaching Reading Comprehension For Efl Students. TEFLIN Journal. 21(1), 27-40

https://doi.org/10.30762/jeels.v2i1

Journal of English Education and Linguistics Studies, 1(2), 100-115. doi:

Keenan, J.M., Betjeman, R.S., \& Olson, R.K. (2008). Reading Comprehension Tests Vary in the Skills They Assess: Differential Dependence on Decoding and Oral Comprehension. Scientific Studies of Reading, 12(3), 281-300. DOI: 10.1080/10888430802132279

Maharsi, I., Ghali, M. I., \&Maulani, S. (2019). High school students' readinghabit and perception on reading for pleasure. International Journal of Indonesian $\begin{array}{llll}\text { Education } & \text { and } & \text { 80aching, } & \end{array}$ https://doi.org/10.24071/ijiet.2019.030108

Muzammil, L., \& Andy. (2017). Teaching proficiency through reading and storytelling (TPRS) as a technique to foster students' speaking skill.Journal of English Education and Linguistics Studies. 1(4), 19-36. doi: https://doi.org/10.30762/jeels.v4i1

Ness, M. K. (2009). Reading comprehension strategies in secondary content area classrooms: Teacher use of and attitudes towards reading comprehension instruction. Reading Horizons, 49(2), 59-85.

Nunan, D. (2003). Language teaching methodology. London: Prentice Hall International.

Perkins, K. (2005). The effect of word frequency and contextual richness on ESL students' word identification abilities. Journal of Research in Reading, 2(6), 119-128. doi: 10.1111/j.1467-9817.1983.tb00246.x

Perwira, S.A., Aswandi., \& Setiawan, S. (2019). Textbook Readability Assessment of K13 English Textbook for the Twelfth Grade. IJET. 8(2),38-47 
Rohman, Abdul. (2017). Improving Students' Reading Comprehension Through Text Structure Tasks. Journal of Linguistic and English Teaching. 2(1), 212.http://dx.doi.org/10.24903/sj.v2i1.74

Syafi'I, M. L. (2015). Smart strategy to boost students' reading comprehension.Journal of English Education and Linguistics Studies, 1(2), 100-115. doi: https://doi.org/10.30762/jeels.v2i1

Topuzkanamis, Ersoy. (2019). Investigation of Reading and Writing Strategies Used by Future Teachers: Do Good Readers Write Well?Advances in Language and Literary Studies. 10(3), 90100.http://dx.doi.org/10.7575/aiac.alls.v.10n.3p.89

Yang, W., Dai, W.,\&Gao, L. (2012). Intensive Reading and Necessity to Integrate Learning Strategies. English Language and Literature. 2(1), 55-63. http://dx.doi.org/10.5539/ells.v2n1p112 